NBER WORKING PAPERS SERIES

IS JAPAN CREATTNG A YEN BLOC IN EAST ASIA AND THE PACIFIC?

Jeffrey A. Frankel

Working Paper No. 4050

NATIONAL BUREAU OF ECONOMIC RESEARCH

1050 Massachusetts Avenue

Cambridge, MA 02138

April 1992

This paper was written for the NBER conference on "Regionalism and Rivalry: Japan and the U.S. in Paciftc Asia," April 3-5. 1992, Del Mar, California. It is forthcoming in a book edited by Jeff Frankel and Miles Kahler. The author would like to thank Menzie Chinn. Benjarnin Chui, Julia Lowell and Shang-Jin Wei for extremely efficient research assistance. He would also like to thank Miles Kahler, Rober Lawrence, and other participants at the Del Mar conference, plus participants at a seminar of Stanford University's Asia/Pacific Research Center, for useful comments. Finally, he would like to thank the Japan-United States

Friendship Commission (an agency of the U.S. govemment) for research support. This paper is part of NBER's research programs in International Trade and Investment and International Finance and Macroeconomics. Any opinions expressed are those of the author and not those of the National Bureau of Economic Research. 
NBER Working Paper \#4050

ApriI 1992

\title{
IS JAPAN CREATING A YEN BLOC IN EAST ASIA AND THE PACIFIC?
}

\begin{abstract}
The paper reaches seven conclusions regarding the Yen Bloc that Japan is reputed to be forming in Pacific Asia, (1) Gravity-model estimates of bilateral trade show that the level of trade in East Asia is biased intra-regionally, as it is within the European Community and within the Westem Hemisphere, to a greater extent than can be explained naturally by distance. One might call these three regions "super-ratural" blocs, in contrast to Krugman's "natura[" trade blocs. (2) There is no evidence of a special Japan effect. (3) Once one properly accounts for rapid growth in Asia, the statistlcs do not bear out a trend toward intra-regional bias of trade flows. (4) The world's strongest trade grouping is the one that includes the U.S. and Canada with the Asian/Pacific countries, i.e.. APEC. (5) There is a blt more evidence of rising Japanese influence in East Asia's financial markets. Tokyo appears to have acquired significant influence over interess rates in a few Asian countries, though overatl lis influence is as yet no greater than that of New York. (6) Some of Japan's financial and monetary influence takes place through a growing role for the $y \mathrm{en}$, at the expense of the dollar. The yen has become relatively more important in exchange rate policies and invoicing of trade and Funance in the region. (7) Bul this trend is less the outcome of Japanese policy-makers' wishes, than of pressure from the U.S. government to intemalionalize the yen.
\end{abstract}

\author{
Jeffrey A. Frankel \\ Departmens of Economics \\ 787 Evans Hall \\ University of Califomia \\ Berkeley, CA 94720 \\ and NBER
}




\section{Is Japan Creating a Yen Bloc in East Asia and the Pacilic?}

A debate got underway in 1991 over whether a global trend toward three economic blocs -* the Westem Hemisphere, centered on the United States; Europe, centered on the European Community; and East Asia, centered on Japan -- is good or bad. Krugman (1991a), Bhagwati (1990, 1992), and Bergsten (1991), argue that the trend is, on balance, bad. Krugman (1991b) and Lawrence (1991c) argue that it is, on balance, good. ${ }^{1}$ Most appear to agree, however, that a trend toward three blocs is indeed underway.

There is no standardly agreed definition of an "economic bloc." A useful definition might be a group of countries who are concentrating their trade and financial relationships with each other, in preference to the rest of the world. One might wish to add to the definition the criterion that this concentration is the outcome of govemment policy, or at least of factors that are non-economic in origin, such as a common language or culture. In two out of the three parts of the world, there have clearly been recent deliberate political steps toward economic integration. In Europe, the previously-lethargic European Economic Community has burst forth with the programs of the Single Market, European Monetary Union, and more. In the Western Hemisphere, we have the Caribbean Basin Initiative and (more seriously) the Canadian-U.S. Free Trade Agreement, followed by a prospective North America Free Trade Area and Enterprise for the Americas Initiative.

\footnotetext{
1 Those who fear the bloes do so because they think they will tend to be protectionist. Frool and Yoffie (1991) in this volume pursue this logic, and point out some implications of foreign direct invest thent. Krugahan (1991b) argues in favor of the three blocs on the grounds that they are "natural, " in a sense explained bejow, Lawrence's (1991c) argument in favor of blocs is that they can cement polilically pro-liberalization sentiment in individual countries.
} 
In East Asia, by contrast, overt preferential trading arrangements or other political moves to promote regional economic integration are lacking, as has been noted by others. ${ }^{2}$ The ASEAN countries (Association of SouthEast Asian Nations), to be sure, are taking steps in the direction of tuming what used to be a regional security group into a free trade area of sorts. But when Americans worry, as they are wont to do, about a trading bloc forming in Asia, it is generally not ASEAN that concerns them. Rather it is the possibility of an East Asia- or Pacific-wide bloc dominated by Japan.

Japan is in fact unusual among major countries in not having preferential trading ariangements with smaller neighboring countries. But the hypothesis that has been put forward is that Japan is forming an economic bloc in the same way that it runs its economy: by means of policies that are implicit, indirect, and invisible. Specifically, the hypothesis is that Japan operates, by means of such instruments as flows of aid, foreign dircet investment, and other forms of finance, to influence its neighbors' trade toward itself. ${ }^{3}$ This is a hypothesis that should not be accepted uncritically, but rather needs to be examined empirically.

After examining some of the relevant statistics, this paper argues that the evidence of an evolving East Asian trade bloc centered on Japan is not as clear as many believe. Trade between Japan and other Asian countries increased substantially in the late 1980s. But intraregional trade bias did not increase, as it did, for example, within the European Community. The phrase "Yen Bloc" could be interpreted as referring to the financial and monetary aspects implicit in the words, rather than to trade flows. The second half of the paper does find

\footnotetext{
2 E.g., Petri (1991 b).

For one of many examples, see Dombusth (1989).
} 
evidence of growing Japanese influence in the Pacific via financial and monetary channels, rather than primarily via trade flows. But it does not find evidence that the country has taken deliberate steps to establish a Yen Bloc.

\section{PART I: IS A TRADE BLOC FORMTNG IN PACIFIC ASIA?}

We must begin by acknowledging the obvious: the greatly increased economic weight of East Asian countries in the world. The rapid outward-oriented growth of Japan, followed by the four East Asian NICs (Newly Industrialized Countries) and more recently by some of the other ASEAN countries, is one of the most remarkable and widely-remarked trends in the world economy over the last three decades. But when one asks whether a yen bloc is forming in East Asia, one is presumably asking something more than whether the economies are getting larger, or even whether economic flows among them are increasing. One must ask whether the share of intra-regional trade is higher, or increasing more rapidly, than would be predicted based on such factors as the GNP or growth rates of the countries involved.

\section{Adjustine Intra-regional Trade for Growth}

Table 1 reports three altemative ways of computing intra-regionat trade bias. The first part of the table is based on a simple breakdown of trade (exports plus imports) undertaken by countries in East Asia into trade with other members of the same regional grouping, versus trade 
with other parts of the world. For comparison, the analogous statistics are reported for Western Europe (the EC Twelve) and for North America (the United States, Canada, and Mexico). The shate of intra-regional trade in East Asia increased from 33 per cent in 1980 to 37 per cent in 1989 . Pronouncements that a clubbisb trade bloc is forming in the region are usually based on figures such as these. But the numbers are deceptive.

All three regions show increasing intra-group trade in the 1980 s. The region that has both the highest and the fastest-increasing degree of intra-regional trade is not Asia but the European Community, reaching 59 per cent in 1989. The share of intra-regional trade in East Asia has rot even been increasing appreciably faster than that in North America.

Quite aside from the comparison with Europe, it is easy to be misled by intra-regional trade shares such as those reported in the first three rows of Table 1 . If one allows for the phenomenon that most of the East Asian countries in the 1980 s experienced rapid growth in total output and trade, then it is possible that there has in fact been no movement toward intraregional bias in the evoiving pattern of trade. The increase in the intra-regional share of trade that is observed in Table 1 could be entirely due to the increase in economic size of the countries. To take the simplest case, imagine that there were no intra-regional bias in 1980 , that each East Asian country conducted trade with other East Asian countries in the same proportion as the latter's weight in world trade (15\% [= 578/3842]). Total trade undertaken by Asian countries increased by 108 per cent in dollar terms over this nine-year period, while total trade worldwide increased by only 53 per cent. Even if there continued to be no regional bias in 1989, the observed intra-regional share of trade would have increased by one-third (to $20 \%$

\footnotetext{
1 These statistics are presented in more detail in Table $]$ in Franke], $1991 \mathrm{c}$.
} 
[ $=1200 / 5892]$ ) due solely to the greater weight of Asian countries in the world economy.

Consider now the more realistic case where, due to transportation costs if nothing else, countries within each of the three groupings undertake trade that is somewhat biased toward trading partners within their own group (East Asia, North America, and the European Community). Although East Asian trade with other parts of the world increased rapidiy [by 93 $\%$ [751.5/388.5]], trade with other Asian countries increased even more rapidly [by $137 \%$ in dollar terms [448/189]]. Does this mean that the degree of clubbishness or within-region bias intensified over this period? No, it does not. Even if there was no increase at all in the bias toward intra-Asian Lrade, the more rapid growth of total trade and output experienced by Asian countries would show up as a rate of growth of intra-Asian trade that was faster than the rate of growth of Asian trade with the rest of the world.

Think of each East Asian country in 1980 as conducting trade with other East Asian firms in the same proportion as their weight in world trade (15\%) multiplied by a regional bias term to explain the actual share reported in Table $1(33 \%)$. Then the regional bias term would have to be $2,18(=.33 / 15)$. An unchanged regional bias tcrm multiplied by the East Asians' 1989 weight in world trade would predict that the 1989 intra-regional share of trade would be 44 per cent $(2.18 \times .20=.436)$. The actual intra-regional share, however, did not increase to nearly this level. Thus the East Asian bias toward within-region trade, far from rising, actually diminished in the 1980s! The implicit intra-regional bias fell to $1.9(=.37 / .20)$, as shown in the middle rows of Table 1 . 


\section{A Test on Bilateral Trade Flows}

The analysis should be elaborated by use of a systematic framework for measuring what patterns of bilateral trade are normal around the world; the so-called "gravity" model." A dummy variable can then be added to represent when both countries in a given pair belong to the same regional grouping, and one can check whether the level and time trend in the East Asia/Pacific grouping exceeds that in other groupings. We do not currently have measures of historical, political, cultural and linguistic ties. Thus it will be possible to interpret the dummy variables as reflecting these factors, rather than necessarily as reflecting discriminatory trade policies. Perhaps we should not regret the merging of these different factors in one term, because as noted there are in any case no overt preferential trading arrangements on which theories of a Japanese trading bloc could rely. ${ }^{6}$

The dependent variable is trade (exports plus imports), in log form, between pairs of countries in a given year. We have 63 countrics in our data set, so that there are 1,953 data points (=63x62/2) for a given year." The goal, again, is to see how much of the high level of trade within the East Asian region can be explained by simple economic factors common to bilateral trade throughout the world, and how much is left over to be attributed to a spectal

\footnotetext{
S See Deartorff (1984, pp.509-04) for a survey of the (short) subject of gravity equations.

SKrugman (1991) has made a crude first pass at applying the gravity model to the question whether Europe and North America are separate trading blocs, but did not get as far as including other countries, or including a variable for distance.

${ }^{7}$ There are some missing values (245 in 1985 for example), normally due to levels of trade too small to be recorded. In the 1990 results reported here, Taiwan trade is missing. Delails on the countries are given in an Appendix.
} 
regional effect."

One would expect the two most important factors in explaining bilateral trade flows to be the geographical distance between the two countries, and their economic size. These factors are the essence of the gravity model. A large part of the apparent bias toward intra-regional trade is certainly due to simple geographical proximity. Indéed Krugman (1991b) suggests it may all be due to proximity so that the three trading blocs are "natural" (as distinet from "unnatural" trading arrangements between distant frading partners such as the United States and Israel). Although the importance of distance and transportation costs is clear, there is not a lot of theoretical guidance on precisely how they should enter. We experiment a bit with functional forms. We also add a dummy "Adjacent" variable to indicate when two countries share a common border.

The equation to be estimated is:

$$
\log \left(T_{i j}\right)=\alpha+\beta_{1} \log \left(G N P_{1} G N P_{j}\right)+\beta_{2} \log \left(G N P / p O P_{i} G N P / P O p_{j}\right)
$$

$+\beta_{3} \log (D I S T A N C E)+\beta_{4}(A D J A C E N T)+\gamma_{1}\left(E E C_{i j}\right)+\gamma_{2}\left(W H_{1 j}\right)+\gamma_{3}\left(A S I A_{1 j}\right)+u_{1 j}$.

The last four explanatory factors are dummy variables.

\footnotetext{
- Details on the data sources, groupings of countries, method for computing distances, etc., are available on request.
} 
Entering GNPs in product form is empirically well-established in bilateral trade regressions. It can be easily justified by the modern theory of trade under imperfect competition. In addition there is reason to believe that GNP per capita has a positive effect, for a given size: as countries become more developed, they tend to specialize more and to trade more.

The results are reported in Tables 2,3 , and 4 . We found all three variables to be highly significant statistically ( $>99 \%$ level). The coefficient on the log of distance was about -.56 , when the adjacency variable (which is also highly significant statistically) is included at the same time. This means that when the distance between two non-adjacent countries is higher by 1 per cent, the trade between them falls by about .56 per cent. ${ }^{10}$ We tested for possible non-linearity in the log-distance term, as it could conceivably be the cause of any apparent bias towaro intraregional trade that is left after controlling linearly for distance. Quadratic and cubic terms tumed out to be not at all significant. We report here onily results without thern.

The estimated coefficient on GNP per capita is about .29 as of 1980 , indicating that richer countries do indeed trade more, though this term declines during the 1980 s, reaching .08 in 1990. The estimated coefficient for the log of the product of the two counties' GNPs is about .75 , indicating that, though trade increases with size, it increases less-than-proportionately (holding GNP per capita constant). This presumably reflects the widely-known pattem that snall

\footnotetext{
The specificalion implies that trade between two equal-sized countries (say, of size ,5) will be greater than trade between a large and small country (say, of size.$S$ and .1 ). This property of models with imperfect competition is not a property of the classical Heckscher-Ohlin theory of comparative advantage. Helpman (1987) and Helpman and Krugman (1985, section 1.5). Foundations for the gravity model are also offered by Anderson (1979) and other papers surveyed by Deardorff (1984, pp.503-06).

10 The coeficient on the log of distance was about . 8 when the adjacency variable was not included.
} 
economies tend to be more open to international trade than larger, more diversified, economies.

If there were nothing to the notion of trading blocs, then these basic variables would soak up all the explanatory power. There would be nothing left to attribute to a dummy variable representing whether two trading partners are both located in the same region. In this case the level and trend in intra-regional trade would be due solely to the proximity of the countries, and to their rapid rate of overall economic growth. But we found that dummy variables for intraregional trade are statistically significant, both in East $\dot{A}$ sia and elsewhere in the world. If two countries are both located in the Western Hemisphere for example, they will trade with each by an estimated $1 / 2$ a per cent more than they would otherwise, even after taking into account distance and the other gravity variables. Intra-regional trade goes beyond what can be explained by proximity, what Krugman (1991b) calls a "natural" trading bloc. We might refer to such intra-regional trade bias as evidence of "super-natural" trading blocs.

When the boundaries of the Asian bloc are drawn along the lines of those suggested by Malaysian Prime Minister Mahatir in his proposed East Asian Economic Caucus, which excludes Australia and New Zealand (and also China, in the version tested here), the coefficient on the Asian bloc appears to be the strongest and most significant of any in the world. Even when the boundaries are drawn in this way, however, there is no evidence of an increase in the intraregional bias of Asian trade during the 1980s: the estimated coefficient actually decreases somewhat from 1980 to 1990 . Thus the gravity results corroborate the back-of-the-envelope calculation reported in the preceding section. The precise partem is a decrease in the first half of the decade, followed by a very slight increase in the second half, matching the results of Petri 
(1991a)." None of these changes over time is statistically significant.

It is perhaps surprising that the estimated level of the intra-regional trade bias was higher in East Asia as of 1980 than in the other two regions. One possible explanation is that there has historically been a sort of "trading culture" in Asia. To the extent that such a culture exists and can be identified with a particular nation or ethnic group, I find the overseas Chinese to be a more plausible factor than the Japanese.

Of the three trading blocs, the EEC and the Western Hemisphere are the two that show rapid intensification in the course of the $1980 \mathrm{~s}$. Both show an approximate doubling of their estimated intra-regional bias coefficients. As of 1980 , trade within the EEC is not strong enough -- after holding constant for the close geographical proximity and high incomes per capita of European countries -- for the bias coefficient of .2 to appear statistically significant. The EEC coefficient increased rapidly in level and significance in the first half of the 1980s, rcaching about .4 in by 1985, and continued to increase a bit in the second half. The effect of two countries being located in Europe per se, when tested, does not show up as being nearly as strong in magnitude or significance as the effect of membership in the EEC.

The Western Hemisplere coefficient experienced all its increase in the second half of the decade, exceeding 9 by 1990 . The rapid increase in the Westem Hemisphere intra-regional bias in the second half of the $1980 \mathrm{~s}$ is in itself an important new finding. The recovery of Latin American imports from the United States after the compression that followed the 1982 debt crisis must be part of this phenomenon. The Canada-U.S. Free 'Trade Agreement signed in 1988 may aiso be part of the explanation.

\footnotetext{
${ }^{11}$ Petri infers, from the datt on intra-regional lrade shares, a decrease in East Asian interdependence in the early 1980 s, followed by a revertal in the second half of the decade.
} 
We consider a sequence of nested candidates for trading blocs in the Pacific. The significance of a given bloc effect tums out to depend on what other blocs are tested at the same time. One logical way to draw the boundaries is to include all the countries with easten coasts on the Pacific, as in the statistics considered in the preceding section. We call this grouping "Asian Pacific" in the tables. Its coefficient and significance level are both higher than the EAEC dummy. When we broaden the bloc-search wider and test for an effect of APEC (Association of Pacific Economic Cooperation), which includes the United States and Canada in with the others, it is highly significant. The significance of the Asian Pacific dummy completely disappears, and that of the EAEC dummy returns.

APEC appears to be the correct place to draw the boundary. When we test for the broadest definition of a Pacific bloc, including Latin America, it is not at all significant, and the other coefficients do not change. (It is called "Pacific Rim" in the tables.) It remains true that the intra-regional biases in the EEC and Westem Hemisphere blocs each roughly doubled from 1980 to 1990 , while intra-regional biases in the Asia and Pacific areas did not increase at all. The only surprising new finding is the APEC effect: the United States and Canada appear to be full partners in the Pacific bloc, even while simultaneously belonging to the significant but distinct Westem Hemisphere bloc. The APEC coefficient is the strongest of any. Its estimate holds relatively steady at $1.3(1980), 1.0(1985)$, and $1.2(1990) .^{12}$

One possible explanation for the apparent intra-regional trade biases within East Asia and

11 Olhers have reported the high volume of trans-Pacific 1rade. But it has been difficult to evaluate such statistics when no accounl is taken of these countries' collective size. A higher percentage of economic activity in a larger region will consist of intra-regional than in s smaller region, even when there is no intra-regional bias, merely because smaller regions tend by their nature to trade across their boundaries more lban larger ones. In the limit, when the unit is the world, 100 per cent of trade is inlra-"regional." 
within the APEC grouping is that transportation between Pacific Asian countries is mostly by water, while transportation among European or Western Hemisphere countries is more often overland, and that ocean-shipping is less expensive than shipping by rail or road. This issue bears further investigation. The issue of water versus land transport should not affect results regarding changes in intraregional trade bias in the $1980 \mathrm{~s}$, however, given that the nature of shipping costs does not appear to have changed over as short a time span as five or ten years.

Several further questions naturally arise. ASEAN negotjated a preferential trading arrangement within its membership in 1977 (although serious progress in removal of barriers did not get underway until 1987$).{ }^{13}$ In early 1992 , the members proclaimed plans for an ASEAN Free Trade Area, albeit with exemptions for many sectors. Does this grouping constitute a small bloc nested within the others? We include in our model a dummy variable for common membership in ASEAN. ${ }^{14}$ It tums out to have a significant coefficient only if none of the broader Asian blocs ate included. The conclusion seems to be that ASEAN is not in fact functioning as a trade bloc.

We know that most East Asjan countries are very open to trade of all sorts. So we added a dummy variable to indicate when at least one of the pair of countries is located in Pacific Asia, to supplement the dummy variable that indicates when both are. Its coefficient is significant, but still leaves a significant coefficient for the East Asian bloc term.

We also know that Singapore and Hong Kong are especially open countries, and engage in a certain amount of entrepot trade. Once again, a dummy variable for these two countries'

\footnotetext{
I3 Jackson (199l).

"In tests similar to ours, Hamilton and winters (1991) found the ASEAN dummy to reflest one of the most significant trading areas in the world.
} 
trade with other Asian Pacific countries is highly significant (with a coefficient of .9) when it is included, but does not otherwise change the results.

We tried a few more extensions as well. We disaggregated trade into manufactured goods, agricultural products, fuels, and other raw materials. The results changed little. Raw materials show the greatest Asian bloc effect if judged by the estimated coefficient. Manufactures shows the greatest effect if judged by t-statistics. Desirable extensions for the future, besides further disaggregation, include adding factor endowment terms.

What about bilateral trade between Asian/Pacific countries and Japan in particular? Like intra-regional trade overall, trade with Japan increased rapidly in the second half of the 1980s. Most of this increase merely reversed a decline in the first half of the 1980 s however. ${ }^{15}$ More importantly, the recent trend in bilateral trade between Japan and its neighbors can be readily explained as the natural outcome of the growth in Japanese trade overall and the growth in trade levels attained by other Asian countries overall. Lawrence (1991b) has calculated that, out of the 28 percentage point increase in the market share of Pacific Asian developing countries in Japanese imports from 1985 to 1988,11 percentage points is attributable to improved competitiveness (as reflected in increased exports from Pacific Asia to worldwide markets), and 18 percentage points is attributable to the commodity mix of these countries' exports. There is no residual to be attributed to Japan's development of special trading relations with other countries in its region. ${ }^{16}$

We confirmed this finding (though without as yet decomposing trade by commodity) by

\footnotetext{
19 Petri $1991 \mathrm{a}$.

If The empirical literature on whether Japan is an outlier in its trading patlems, particularly with respect to imports of manufactures, includes Saxonhouse (1989), Noland (1991) and Lawrence (1991a), among others.
} 
adding to our gravity model a separate dummy variable for bilateral Asian trade with Japan in particular. It was not even remotely statistically significant in any year, and indeed the point estimate was a small negative number. (The results are not reported in this version of the paper.) Thus there was no evidence that Japan has established or come to dominate a trading bloc in Asia. ${ }^{17}$

To summarize the most relevant effects, if two countries both lie within the boundaries of APEC, they trade with each other a little over 1 per cent more than they otherwise would, The nested EAEC bloc is less strong, and has declined a bit in magnitude and significance during the course of the 1980s. The Westem Hemisphere and EC blocs, by contrast, intensified rapidly duning the decade. Indeed, by 1990 , the Western Hemisphere bloc was stronger than the EAEC bloc, if one takes into account the existence of the APEC effect. There was never a special Japan effect within Pacific Asia.

In short, beyond the evident facts that countries near each other trade with each other, and that Japan and other Asian countries are growing rapidly, there is no evidence that Japan is concentrating its trade with other Asian countries in any special way, nor that they are collectively moving toward a trade bloc in the way that Western Europe and the Westem Hemisphere appear to be. We now turn from trade to finance.

\footnotetext{
iT To save space, the results for the Japan dummy are not reported in this version of the paper. Nor are the results showing the effects of the two dummy variables meant to capture effects of openness of Asian countries in general and of Fong Kong/Singapore in particular. [Tables showing these results appeared with the April 1992 conference version of this paper.]
} 


\section{PART II. JAPAN'S FINANCIAL INFLUENCE IN THE REGION}

In the case of financial flows, proximity is less important than it is for trade flows. For some countries the buying and selling of foreign exchange and highly-rated bonds is characterized by the absence of significant govemment capital controls, transactions costs or information costs. In such cases, there would be no particular reason to expect greater capital flows among close countries than distant ones, Rather, each country would be viewed as depositing into the world capital pool, or borrowing from it, whatever quantity of funds it wished at the going world interest rate. Thus even if we could obtain reliable data on bilateral capital flows (which we cannot), and whatever pattem they happened to show, such statistics would not be particularly interesting.

\section{Tokyo's In luence on Regional Financial Markets}

Many Asian countries still have substantial capital controls, and financial markets that are in other respects less than fully developed. Even financial markets in Singapore and Hong Kong, the most open in Asia, retain some minor frictions. Where the links with world capital markets are obstructed by even small bariers, it is an inleresting question to ask whether those links are stronger with some major financial centers than with others. This question is explored econometrically below.

Information costs exist for equities, and for bonds with some risk of default. These costs. may be smaller for those investors who are physically, linguistically, and culturally close to the nation where the borrower resides. Proximity clearly matters as well in the case of direct 
investment, in part because much of direct investment is linked to trade, in part because linguistic and cultural proximity matter for direct investment.

\section{Foreign Direct Investment}

Table 5 shows the standard Ministry of Finance figures for Japanese direct investment. The steady stream of direct investment by Japanese firms in East Asia and the Pacific (including Australia) has received much attention. But the table shows that, whether measured in terms of annual flows or cumulated stocks, Japan's direct investment in the region is approximately equal to its investment in Europe, and is much less than its investment in North America. ${ }^{18}$

It has been argued that once one scales the Table 5 figures for GNP among the host countries, an Asian bias to Japanese direct investment might indeed appear. ${ }^{19}$ But if one scales the FDI figures by the host region's role in world trade, one finds that Japan's investment in Asia and Oceania is almost exactly in proportion to their size. There is no rcgional bias. Its FDI in the United States and Canada, on the other hand, is more than twice what one would expect from their share of world trade. Japan's investment in Europe is about half the continent's share of trade.

Furthermo:e, Ramstetter (1991a, p.95-96; 1991b, p.8-9) has forcefully pointed out that the standard Ministry of Finance figures on Japanese foreign direct investment actualiy represen। statistics on investment either approved by or reported to the govemment, and greatly overstate the extent of true Japanese investment in developing countries. The more accurate balance of

\footnotetext{
See aiso Komiya and Wakasugi (1991).

${ }^{19}$ Nigel Holloway, "Half-full, half empty," Far Eastem Economic Review, December 1991, p.69.
} 
payments data from the Bank of Japan show a smaller percentage of investment going to Asia.

\section{Tokyo rs, New York Elfects on Assian Interest_Rates}

Statistics also exist on Japanese portfolio investment. But, in the case of portfolio capital, looking at quantity data is not as informalive as looking at price data - that is, at interest rates. For one thing, the quality of the data on interest rates is much higher than the quality of the data on capital flows. For another, the interest rate test is more appropriate conceptually. If the potential for arbitrage keeps the interest rate in a given Asian country closely in line with, say, Tokyo interest rates, then this constitutes good evidence of close links between the two national capital markets, even if the amount of actual arbitrage or other capital flow that takes place within a given period happens to be small.

Many East Asian countries have moved to liberalize and intemationalize their financial markets over the last ten to fifteen years. ${ }^{2}$ A number of studies have documented Japan's removal of capital controls over the period 1979-84 by looking at the power of arbitrage to equalize interest rates between Tokyo and New York or London. ${ }^{21}$ Australia and New Zealand, while lagging well behind Japan, also show signs of liberalization duning the course of the $1980 \mathrm{~s} .{ }^{22}$ Hong Kong and Singapore register impressively open financial markets,

\footnotetext{
D Frankel (1991a) presents the 1980s evidence for Japan, Australia, New Zealand, Singapore, Hong Kong and Malaysia. Faruqe (1991) examines interest differentials for Korea, Malaysia, Singapore and Thailand (vis-a-vis yen interest rates in London), but does not take into account exclbange rate expectations.

21 These include Otani and Tiwari (1981), Ito (1986), and Frankel (1984). The inlerest rates in the calculations are covered on the forward exchange or Eurocurrency markets so as to avoid exchange risk. [Tests that look at real or uncovered interest differentials, rather than covered inlerest differentials, include Ito (i988) and Fukao and Okuba.]

2 The frequently large negative covered differential that had been observed for Australia up to mid-1983 (see, e.g., Argy, 1987) largely vanished thereafter.
} 
showing smaller intercst differentials even than some open European countries like Germany. (Hong Kong has long had open capital markets. Singapore undertook a major liberalization in 1978, though it has tried to segment its domestic money market from its offshore "Asia dollar market. ${ }^{23}$ ) Malaysia has officially liberalized, following Singapore, ${ }^{24}$ though its covered differential has remained considerably higher.

We can apply a simple test to the hypothesis that a particular Asian country is dominated financially by Japan, versus the alternative hypothesis that ties to capital markets in the other industrialized counitries are equally strong. We run the following OLS regression to see how the interest rate in a typical Asian country depends on interest rates in Tokyo and New York.

$$
i_{t}^{a}=\alpha+\beta_{1} \dot{i}_{t}^{T}+\beta_{2} i_{t}^{N T}+\epsilon_{t}
$$

Under the null hypothesis that the country's financial markets are insufficiently developed or libcralized to be directly tied to any foreign financial markets, the coefficients on foreign interest rates should be zero. Under the alternative hypothesis that the country's financial markets are closely tied to those in Tokyo, the coefricient on Tokyo interest rates should be closer to 1 than to 0; and similarly for New York. ${ }^{2 s}$

Table 6 presents estimates for three-month interest rates in Hong Kong and Singapore. For the Hong Kong interest rate, the influence of the New York market appears very strong.

\footnotetext{
${ }^{23}$ See Moreno (1988). Edwards and Khan (1985) includes another test of covered interest parity for Singapore.

24 Abidin (1986) and Glick and Hutchison (1990, p.45).

It It should be noted that if capital markets in Tokyo and New York are closely tied to each other, as they indeed are, then multicollinearity might make it difficult to obtain statistically significant estimates. But this does not arean that there is anylhing wrong with the test. A finding that the coefficient on the Tokyo interest rate is statistically greater than 0 , or than the coefficient on the New York interest rate, remains valid.
} 
This is not surprising: not only does the Colony have open financial markets, but its currency has since October 1983 been pegged to the U.S. dollar, ${ }^{26}$ so that there is nothing to inhibit perfect arbitrage between its interest rates and U.S. interest rates. Neither Tokyo, London, nor Frankfurt, has significant influence in Hong Kong on average over the sample period (from 1976 to 1989). For the Singapore interest rate, the influence of New York is again very significant; but now there is also a significant, though smaller, weight on Tokyo. The evidence suggests that both countries have had open financial markets ever since the mid-1970s, with New York having the dominant influence, but with Tokyo also having a one-quarter effect in the case of Singapore.

To see whether the influence of the foreign financial centers changed over the course of the sample period, we can allow for time trends in the coefficients, also reported in Table 6. For Hong Kong, it is clear that London used to have a strong influence, and equally clear that the British influence has been diminishing over time. For Singapore, there is no sign of change in New York's role, but there is weak evidence of a role for Frankfurt that has been gradually diminishing over time, and of a gradually increasing role for Tokyo.

Similar tests were also run for four other Pacific countries: Australia, New Zealand, Taiwan and Korea (not reported here, to save space). There is evidence of a London effect in Australia that has been slowly increasing during the sample period, and a Frankfurt effect in New Zealand that gave way to a Tokyo effect late in the sample period. [There also appears a Frankfurt effect in Taiwan and Korea with little time trend.]

Overall, there is only weak evidence in Table 6 of a special role for Tokyo as a financial

\footnotetext{
¿ See, e.g. Balassa and Williamson (1990, p.32).
} 
center exerting influence in its part of the world. But during most of the sample period examined, most Asian countries had not yet opened their financial markets to extemal influence by any foreign center.

The foregoing tests of quarterly data will now be expanded to an analysis of monthly data for the six Pacific Asian countries, from the mid-1970s to $1990 .{ }^{27}$ In each case, we test for the influence of all four financial centers: New York, London, Frankfurt, and Tokyo.

When local interest rates are regressed against foreign interest rates, the U.S. is the dominant influence in each of the four East Asian NICs, though the Japanese interest. rate is also statistically significant in Korea and Singapore. In Australia and New Zealand, only the British interest rate is important. (The Japanese interest rate actually appears with the wrong sign, as does the U.S. interest rate in the case of New Zealand.) When the regressions are run on first differences (rather than levels), as they probably should be, the significance levels fall sharply. In the case of Singapore, the U.S. interest rate is still the dominant influence, but the results for the others are less clear.

We can add an interactive time trend to see if the foreign influences change over the sample period. The United Kingdom is losing influence in Hong Kong, where the U.S. gains at its expense, and Singapore, where Japan is the one to gain at the U.K.'s expense. More surprisingly, Japan appears to be losing influence in Taiwan, at the expense of Germany, and in Korea and Australia, at the expense of the U.K. Again, when these tests are run on first differences, significance levels disappear. During most of the sample period, financial markets

\footnotetext{
${ }^{27}$ The full sample runs from March 1973 to Decenber 1990, but data availability restricts the sxmple for many countries. One country has less than ten years of data available: Taiwan, which nuss only from May 1983 to Aprif 1989. Details are available in an Appendix on request. [These results may replace Table 6 (which is taken from Frankel, 1991c) in the final version of the paper.]
} 
in most of these countries were insufficiently liberalized to respond to foreign interest rates, regardless of nationality.

These tests leave some important questions unanswered. First, what would such tests show for the last three years? Economic relationships have been changing rapidly in international financial markets. Korea and Tajwan, for example, have begun to liberalize and intemationalize only very recently. Second, are the barriers that remain between a given country and the major world financial centers due to cumency factors or country factors? Most of the Asian countries experience frequent changes in their exchange rates against the yen and the dollar. Financial markets in a country like Singapore could be very open and yet observed interest rates could differ from those in Tokyo or New York because of premiums meant to compensate investors for the possibility of changes in the exchange rate. The question of whether the yen is playing an increasing role in the exchange rate policies of East Asian countries is an important one to address, but it should be kept distinct from the question whether Financial links to Tokyo (irrespective of currency) are strengthening.

Table 7 analyzes the determination of interest rates in five Pacific countries with monthly data for 1988-91, a time period more recent than that in Table 6 . There is more evidence of an important role on the part of Tokyo than there was in the earlier period. For Singapore, where the influence of Tokyo in Table 6 was less than New York but rising over time, estimates in the first row, based simply on interest rates, suggest that the Japanese financial center has now surpassed its American rival. For Taiwan, Tokyo dominates so strongly that New York doesn't even seem to matter. For Hong Kong and Australia, on the other hand, New York dominates. For Korea, the two major financial centers appear to be 
equally strong.

As noted above, a country could have close financial ties with a foreign country and yet, if exchange rate changes are important, the simple regression against the foreign interest rate would be inappropriately designed to show this relationship. We can take out currency factors by using the forward exchange market. We simply express the foreign interest rates so as to be "covered" or hedged against exchange risk. Doing so in Table 7 changes the results for Australia and Singapore toward a Tokyo effect that is smaller than the New York effect. ${ }^{28}$ (Usable forward rate data are not available for the other countries.)

For four of these countries, there exists another way of correcting for possible exchange rate changes: direct data on forecasts of market participants coliected in a monthly survey by the Curjency Forecaster's Digest of White Plains, N.Y. ${ }^{29}$ One advantage of using the survey responses to measure expected exchange rate changes is that the data allow us to test explicitly whether there exists an exchange risk premium that creates an intemational differential in interest rates even in the absence of barriers to international capital flows. Such a differential would be compensation to risk-averse investors for holding assets that they view as risky. ${ }^{30}$ An

27 For the case of Australia, the coefficient on the covered foreign interest rate is close enough to 1 to constitute statistical support of the hypothesis that "covered interest parity" holds. That is, capital controls and other barriers to the movement of capital between Sydney and New York are close to zero. (The Durbin-Watson statistics improve substantially when the forward rates are included, confirming that the equation that uses covered interest rates is a more appropriate specification.)

7 The Currency Forecasters' Digest data is proprietary, and was obtained by subscriplion by the Institute for Intemational Econorics.

30 The forward rate data allow us to eliminate factors associated with the currency in which countries' assets are denominated, but they do not allow us to distinguish between two currency factors: the excbange risk premium and expectations of depreciation. For the case of Australia, for example, the support for covered interest parity suggests that barriers to the movement of capital between Sydney and New York are low, and so differences in interest rates are due to currency factors. But when the Australian interest rate is observed to exceed the U.S. interest rate, is this because the Australian dollar is confidently expected to depreciate, or is it because investors have no idea what the exchange rate wil] do and demand to be compensated for this risk? The survey data may be 
advantage of the Currency Forecasters' Digest data in particular is that they are available even for countries like Taiwan and Korea where financial markets are less developed. A potential disadvanlage is the possibility that survey data measure the expectations of market participants imperfectly.

For Singapore, the survey data corroborate the finding from the forward rate data that, once expected depreciation is eliminated as a factor, the New York effect dominates the Tokyo effect. For Korea, the survey data also show that the Tokyo effect becomes sthaller than the New York effect. For Australia and Taiwan, both effects largely disappear.

\section{The Role of the Yen in Asian Exchange Rate_Policies}

The finding that eliminating exchange rate expectations from the calculation leaves Tokyo with relatively little effect on local interest rates in most of these countries does not mean that the Japanese influence is not strong. It is likely, rather, that much of the influence in the Pacific comes precisely through the role of the yen. If Pacific countries assign high weight to the yen in setting their exchange rate policies, then their interest rates will be heavily influenced by Japanese interest rates.

No Asian or Pacific countries have ever pegged their currencies to the yen in the postwar period. But neither are there any Pacific countries that the Intemational Monetary Fund classifies as still pegging to the U.S. dollar. (As already mentioned, Hong Kong pegs to the dollar; but the Colony is not an official member of the IMF.) Malaysia and Thailand, and a number of Pacifie island countries, officially peg to a basket of major currencies and are thought

able to distinguish between these two hypotheses, whereas the forward rate data cannot. 
to give weight to both the dollar and yen, but the weights are not officially announced.

It is interesting to estimate econometrically the weights given to the dollar, yen, and other major currencies in exchange rate policies of Asian/Pacific countries, especially those who follow a basket peg but do not officially announce the weights. This involves regressing changes in the value of the currency in question against changes in the value of the yen, doliar, etc.

There is a methodological question of what numeraire should be used to measure the value of the currencies. A simple solution is to use the SDR as numeraire. This approach suffers from the drawback that the SDR is itself a basket of five major currencies including the dollar and yen. An afternative approach that is a little neater theoretically is to use purchasing power over local goods (the inverse of the local price level) as the numeraire. Whatever the numeraire, under the null hypothesis that a particular currency is pegged to the dollar or yen, or to a weighted basket, the regression results should show this clearly, featuring even a high $\mathbf{R}^{2}$. We focus here on the purchasing power measure.

Regressions of chasges in the real value of the Hong Kong dollar against changes in the value of the five major currencies show highly significant coeficicients on the U.S. doliar during the periods $1974-80$ and 1984-90 [not reported here]. The weight on the dollar is statistically indistinguishable from 1 during most of the latter 7-year period, and the $R^{2}$ reaches .96 during the last four years, Occasional sub-periods show apparently significant weights on other currencies (the yen curing 1979-81, the franc during 1983-85, and the mark during 1986-88). Overall, however, the numbers bear out Hong Kong's peg to the dollar.

Regressions of changes in the real value of the Malaysian ringgit against the five major currencies, reported in Table 8a, give a large significant weight to the dollar. Some sub-periods 
show a significant weight on the mark, and during $1986-88$ even the pound is significant. But the yen is not significant during any three-year sub-period. The constant term is negative (and statistically significant), indicating a trend depreciation, and the $R^{3}$ is fairly low, indicating that the basket "peg" was loose (even if one allows for a crawling peg). ${ }^{31}$

The Singapore dollar shows significant weights (of about .2 each) on the U.S. dollar and mark during the period 1974-77. The regression for 1977-79 shows a rough basket peg $\left(R^{2}=.83\right)$ with significant weights of .09 on the yen, .47 on the dollar, .25 on the mark, and .09 on the pound. The weight on the dollar diminishes thereafter, and the weight on the yen increases. By 1983-85, the yen weight (at a significant .20) has temporarily passed the dollar weight (at a significant .19). From 1986 to 1990 only the dollar is significant.

The results for the real value of the Thai baht, reported in Table $8 \mathrm{~b}$, show a very close peg to the dollar from 1974 to 1980 , whereupon the dollar weight falls somewhat. Beginning in 1986, a pattern emerges of significant weights on the yen and pound, in addition to the dollar. During the period $1988-90$, the baht exhibits a close-to-perfect peg $\left(R^{2}=99\right)$ to a basket with estimated weights of .82 on the dollar, .13 on the yen, .06 on the mark, and .02 on the pound.

Korea also claimed to have a sort of basket peg in the 1980 s, but with large adjustments. Regressions of the change in the real value of the won show a statistically significant weight on the value of the dollar during the period April 1980 to March 1986, with an estimated coefficient of .4 to .5. (The Canadian dollar, which was reputed to be included in the Korean basket, also shows up with a significant coefficient of .2 during part of the period.) There is a significant constant term (the "alpha") during this period: the value of the won declined during the early

3 This tums out to be true of almost all currencies worldwide that purport to be on a basket peg (excluding a peg to the SDR). 
1980 s, whether measured by inflation or depreciation, relative to foreign currencies. The dollar, like the other major currencies, is insignificant during the period April 1985 to March 1987. Its influence re-emerges from April 1986 to March 1988. But then during the final two-year sub-period, April 1988 to March 1990, the yen (with a highly significant coefficient estimated at .18) suddenly eclipses the dollar (with an insignificant coefficient of .11). ${ }^{32}$

To summarize, there is some evidence of increased yen influence in the case of the Singapore dollar in the early $1980 \mathrm{~s}$ and the Thai baht in the late $1980 \mathrm{~s}$. The only place where the yen appears to have become as important as the dollar is Korea in the period since 1988 .

\section{The Role of the Yen in Reserves and Invoicing}

There is other evidence that the yen is playing an increasing role in the region. As Table 9 shows, Asian central banks in the course of the 1980 s increased their holdings of yen from 13.9 per cent of their foreign exchange reserve portfolios to 17.1 per cent. ${ }^{33}$ Foreign exchange market trading in the regional financial centers of Singapore and Hong Kong, though still overwhelmingly conducted in dollars, now shows a much higher proportion of trading in yen than is the case in Europe. ${ }^{34}$

The yen is also being used more widely to invoice lending and trade in Asia. The countries that incurred large international debts in the 1970 s and early $1980 \mathrm{~s}$ subsequently shifted

35 The results for the won are reported in Frankel (1992). [With value measured in terms of purchasing power. Value is messured also in terms of the SDR in a related paper to be published by the Hoover lnstibution, but the regressions are against the dollar and yen alone.]

Ja The deutsche mark and \$wiss franc are the two currencies that suffered the largest loss in share in the region.

${ }^{4}$ Tavjas and Ozeki (1992, p.35). 
the composition away from dollar-denominated debt and toward yen-denominated debt. Table 9 shows that the yen share among five major Asian debtors nearly doubled between 1980 and 1988 , entirely at the expense of the dollar. Table 10 shows that the share of trade denominated in yen is greater in Southeast Asia than in other regions, and that was an especially rapid increase from 1983 to 1990 in the share of Southeast Asian imports denominated in yen. ${ }^{35}$

\section{PART IIL: CONCLUSIONS}

We may draw eight conclusions.

(1) The level of trade in East Asia, like trade within the European Community and within the Westem Hemisphere, is biased toward intraregional trade, to a greater extent than can be explained naturally by distance, By way of contrast to Knugman's "natural" trade blocs, one might call these three regions "super-natural" blocs. (2) There is no evidence of a special Japan effect within Asia. (3) Although growth in Japan, the four NICs, and other East Asian countries, is rapidly increasing their weight in world output and trade, the statistics do not bear out a trend toward intra-regional bias of trade and direct investment flows. (5) The intraregional trade bias did increase in Europe in the 1980s, іл the Western Hemisphere in the late 1980s, and in the grouping that includes the U.S. and Canada together with the Asian/Pacific countries, i.e., APEC. (6) The APEC trade grouping appears to be the world's strongest, whether judged by rate of change of intra-group bias or (as of 1990) by level of bias. Far from

\footnotetext{
3 Tavlas and Ozeki $(1991,92)$ give further stalistics and discussion.
} 
being shut out of a strong Asian bloc centered on Japan, the United States and Canada are in the enviable position of belonging to both of the world's two strongest groupings.

(7) There is more evidence of rising Japanese influence in the East Asia's financial markets than is the case for trade. Tokyo appears to have recently acquired a dominant influence over interest rates in Singapore and Taiwan. It also has important and increasing effects on interest rates elsewhere in the Pacific, though overall its influence is as yet no greater than that of New York. (8) Some of Japan's financial influence takes place through a growing role for the yen, at the expense of the dollar. There has been a gradual increase in the yen's relative importance in invoicing of trade and finance in the region, and in some countries' exchange rate policies.

This still leaves a question raised at the beginning of this essay. Are the financial and monetary trends the outcome of deliberate policy measures on the part of Japan? Graduallyincreasing use of the yen intemationally is primarily the outcome of private decisions by importers, exporters, borrowers and lenders. It is difficult to see signs of deliberate policy actions taken by the Japanese govemment to increase its financial and monetary influence in Asia. To the contrary, at least until recently, the Japanese government has resisted any tendency for the yen to become an intemational currency in competition with the dollar.

It has been the U.S. government, in the Yen/Dollar Agreement of 1984 and in subsequent negotiations, that has been pushing Japan to intemationalize the yen, to promote its worldwide use in trade, finance, and central bank policies. ${ }^{36}$ It has also been the U.S. govemment that has been pushing Korea and other East Asian NICs to open up their financial markets, thereby

\footnotetext{
${ }^{36}$ Frankel (1984).
} 
allowing Japanese capital and Japanese financial instioutions to enter these countries. It has again been the U.S. government that has been pushing Korea and Taiwan to move away from policies to stabilize the value of their currencies against the dollar. ${ }^{37}$ The increasing role of the yen in Pacific Asia may or may not be a good idea. But it is an idea that originated in Washington, not in Tokyo.

\section{References}

Abidin, A.Z., 1986, "Financial Reform and the Role of Foreign Banks in Malaysia," in Financial Policy and Reform in Pacific Basin Countries, Hanson Cheng, ed. (Lexington Books: Lexington, MA), pp.305-309.

Anderson, James, 1979, "A Theoretical Foundation for the Gravity Equation," American Economic Review 69, 1, March, 106-116.

Argy, Victor, 1987, "International Financial Liberalisation -- The Australian and Japanese Experiences Compared," Bank of Japan Monetary and Economic Studies 5, 1, 105-168.

Balassa, Bela, and John Williamson, 1990, Adjusting to Success: Balance of Payments Policy in the East Asian NICs, Policy Analyses in International Economics 17, Institute for International Economics: Washington, DC), April.

Bergsten, C.Fred, in "Comment on Krugman," in Policy Implications of Trade and Currency Zones, A Symposium Sponsored by the Federal Reserve Bank of Kansas City, Jackson Hole, Wyoming, August, p.43-57.

Bhagwati, Jagdish, 1990, "Regional Accords Be-GATT Trouble For Free Trade, " Wall Street Joumal, Dec. 5.

\footnotetext{
${ }^{37}$ Balassa and Williamson (1987), Noland (1990) and Frankel (1989). Financial negotiations between the U.S. Treasury and the governments of Korea and Taiwan were a response to congressional pascage of the 1988 Omnibus Trade Bill.
} 
Bhagwati, Jagdish, 1992, "Regionalism vs. Multilateralism: An Overview, "Conference on New Dimensions in Regional Integration, World Bank, Washington, D.C., April 2-3.

Deardorff, Alan, 1984, "Testing Trade Theories and Predicting Trade Flows," in R.Jones and P.Kenen, eds., Handbook of International Economics yol. 1 (Elsevier Science Publishers: Amsterdam), Ch.10, 467-517.

Dombusch, Rudiger, 1989, "The Dollar in the 1990s: Competitiveness and the Challenges of New Economic Blocs," in Monetary Policy Issues. in the 1990s (Federal Reserve Bank of Kansas City).

Edwards, Sebastian and Mohsin Khan, 1985, "Interest Rate Determination in Developing Countries: A Conceptual Framework, "LMF. Staff Papers 32, Sept., 377-403.

Eken, Sena, 1984, "Integration of Domestic and International Financial Markets: The Japanese Experience," Staff Papers 31, International Monetary Fund, 499-548.

Faruqee, Hamid, 1991, "Dynamic Capital Mobility in Pacific Basin Developing Countries: Estimation and Policy Implications," Working Paper 91/115, International Monetary Fund, November.

Frankel, Jeffrey, 1984, The Yen/Dollar Agreement: Liberalizing Japanese Capital Markets, Policy Analyses in International Economics no. 9 (Institute for International Economics: Washington, D.C.).

Frankel, Jeffrey, 1989, "And Now Won/Dollar Negotiations? Lessons From the Yen/Dollar Agreement of 1984" in Korca's Macroeconomic and Financial Policies (Korean Development Institute: Seoul), December.

Frankel, Jeffrey, 1991a, "Quantifying International Capital Mobility in the 1980's," in National Saving and Ecanomic Performance, D. Bernheim and J. Shoven, eds. (University of Chicago Press: Chicago), 227-260.

Frankel, Jeffrey, 1991b, "The Japanese Cost of Finance: A Survey, "Financia' Managcnent, Spring, $95-127$

Frankel, Jeffrey, 1991c, "Is a Yen Bloc Forming in Pacific Asia?" in Finance and the Intemational Economy, The AMEX Bank Review Prize Essays, edited by R.O'Brien, Oxford University Press, UK.

Frankel, Jeffrey, 1992, "Liberalization of Korea's Foreign Exchange Markets, and Tests of U.S. versus Japanese Influence," forthcoming, Seoul Joumal of Economics." [An earlier version was presented at a conference on U.S.-Korea Economic Relations, and is forthcoming, R. Myers, ed., Hoover Institution.]

Froot, Kentieth, and David Yoffie, 1991, "Strategic Trade Policies in a Tripolar World," 
Working Paper No. 91-030, Haryard Business School; revised.

Fukao, Mitsuhiro and T. Okubo, "International Linkage of Interest Rates: The Case of Japan and the United States, "Intemational Economic Review 25, February.

Glick, Reuven, 1987, "Interest Rate Linkages in the Pacific Basin," Federal Reserve Bank of San Francisco Economic Review No. 3, pp.31-42.

Glick, Reuven, and Michael Hutchison, 1990, "Financial Liberalization in the Pacific Basin: Implications for Real Interest Rate Linkages," Joumal of the Japanese and Intemational Economies 4, 36-48.

Hamilton, Carl, and L.Alan Winters, 1991, "Opening Up Intemational Trade in Eastem Europe," Economic Policy Panel, Prague, October.

Helpman, Elhanan, 1987, "Imperfect Competition and Intemational Trade: Evidence from Fourteen Industrial Countries," Joumal of the Japanese and Intemational Economies 1, $62-81$.

Helpman, Elhanan and Paul Krugman, 1985, Market Structure and Foreign Trade, Cambridge, MA: MTT Press.

Ito, Takatoshi, 1986, "Capital Controls and Covered Interest Parity," NBER working paper no. 1187, and Economic Studies Quarterly 37, 223-241.

Ito, Takatoshi, 1988, "Use of (Time-Domain) Vector Autoregressions to Test Uncovered Interest Parity," Review of Economics and Statistics 70, 296-305.

Jackson, Tom, 1991, "A Game Model of ASEAN Trade Liberalization," Open Economies Review 2, no.3, pp. 237-254.

Komiya, Ryutaro and Ryuhei Wakasugi, 1991, "Japan's Foreign Direct Investment," Annals of the American Academy of Political and Social Science, Jan.

Krugman, Paul, 1991a, "Is Bilateralism Bad?" in E.Helpman and A.Razin, eds., Intemational Trade and_trade_Policy, Cambridge, MTT Press.

Krugman, Paul, 199 1b, "The Move Toward Free Trade Zones, " in Policy Implications of Trade and Cumency Zones, A Symposium Sponsored by the Federal Reserve Bank of Kansas City, Jackson Hole, Wyoming, August, p.7-42.

Lawrence, Robert, 1991a, "How Open is Japan?" in Trade With Japan: Has the Door Opened Wider?, Paul Krugman, ed., (University of Chicago Press, Chicago), 9-50.

Lawrence, Robert, 1991b, "An Analysis of Japanese Trade with Developing Countries," Brookings Discussion Papers No. 87, April. 
Lawrence, Robert, 1991c, "Emerging Regional Arrangements: Building Blocks or Stumbling Blocks?" in Finance and the International Economy, The AMEX Bank Review Prize Essays, edited by R.O'Brien, Oxford University Press, UK.

Moreno, Ramon, 1988, "Exchange Rates and Monetary Policy in Singapore and 'Taiwan," in Monetary Policy in Pacific Basin Countries, Hanson Cheng, ed, (Kluwer Press: Boston).

Noland, Marcus, 1990, Pacific Basin Developing Countries: Prospects for the Future (Institute for International Economics: Washington, D.C.).

Noland, Marcus, 1991, "Public Policy, Private Preferences, and the Japanese Trade Pattern," Institute for Intemational Economics, Washington, D.C., November.

Otani, Ichiro, 1983, "Exchange Rate Instability and Capital Controls: The Japanese Experience 1978-81," in: D. Bigman and T. Taya, eds., Exchange_Rate and Trade Instability: Causes. Consequences and Remedies, (Ballinger, Cambridge, MA).

Otani, I., and S. Tiwari, 1981, "Capital Controls and Interest Rate Parity: The Japanese Experience, 1978-1981, IMF Staff Papers 28, 793-815, Dec.

Petri, Peter, 1991a, "Japanese Trade in Transition: Hypotheses and Recent Evidence," in Trade With Japan: Has the Door_Opened Wider?, Paul Krugman, ed, (University of Chicago Press, Chicago).

Petri, Peter, 1991b, "One Bloc, Two Blocs or None? Political-Economic Factors in Pacific Trade Policy," Economics Working Paper No. 297, Brandeis University, April.

Ramstetter, Eric, 1991a, "Regional Patterns of Japanese Multinational Activities in Japan and Asia's Developing Countries," Economic and Political Studies Series No. 74, Kansai University, Osaka.

Ramstetter, Eric, 1991b, "An Overview of Multinational Firms in Asia-Pacific Economies: An Introduction to the Commonplace Ignorance," Faculty of Economics, Kansai University, Osaka.

Saxonhouse, Gary, 1989, "Differentiated Products, Economies of Scale, and Access to the Japanese Market," in Robert Feenstra, ed., Trade Policjes for International Competitiveness (University of Chicago Press, Chicago), 145-174.

Schott, Jeffrey, 1991, "Trading Blocs and the World Trading System," The World Economy 14, no.1, March.

Tavlas, George and Yuzuru Ozeki, 1991, "The Japanese Yen as an International Currency," IMF Working Paper WP/91/2, International Monetary Fund, Jan.

Tavlas, George and Yuzuru Ozeki, 1992, The Intemationalization of Cunencies: An Appraisal of the Japanese Yen, Occasional Paper 90, Intemational Monetary Fund, Washington, D.C., Jan. 
Table 1: Summary Measures of Intra-regional Trade Biases

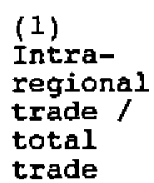

(2)

Intra-

regional

bias,

holding

constant

for bize

of exports

\section{Pacific}

Asia

1980

1986

1989

1980

1989

.33

.32

.37

2.2

1.9

\section{Pacific Aeia}

\section{(3)}

holding

constant

for GNP,

population,

distance, etc. 1990

.70

.40

.60
North

America

.32

.35

.36

1.9

1.3

1.9

1.5

European

commusity

.51

.57

.59

Hestern

Hemisphere

European
Community

.53

.23

.44

.34

.97

.46

Sources:

(1) Schott (1991) and Direction of Trade, International Monetary Fund, as computed in Frankel (1991c).

(2) Computed as the ratio of (1) to shares of world trade, as described in text.

(3) Gravity regressions, reported in Tables 2,3 , and 4 , respectively. They include also significant coefficients on the APEC bloc, among other variables. 


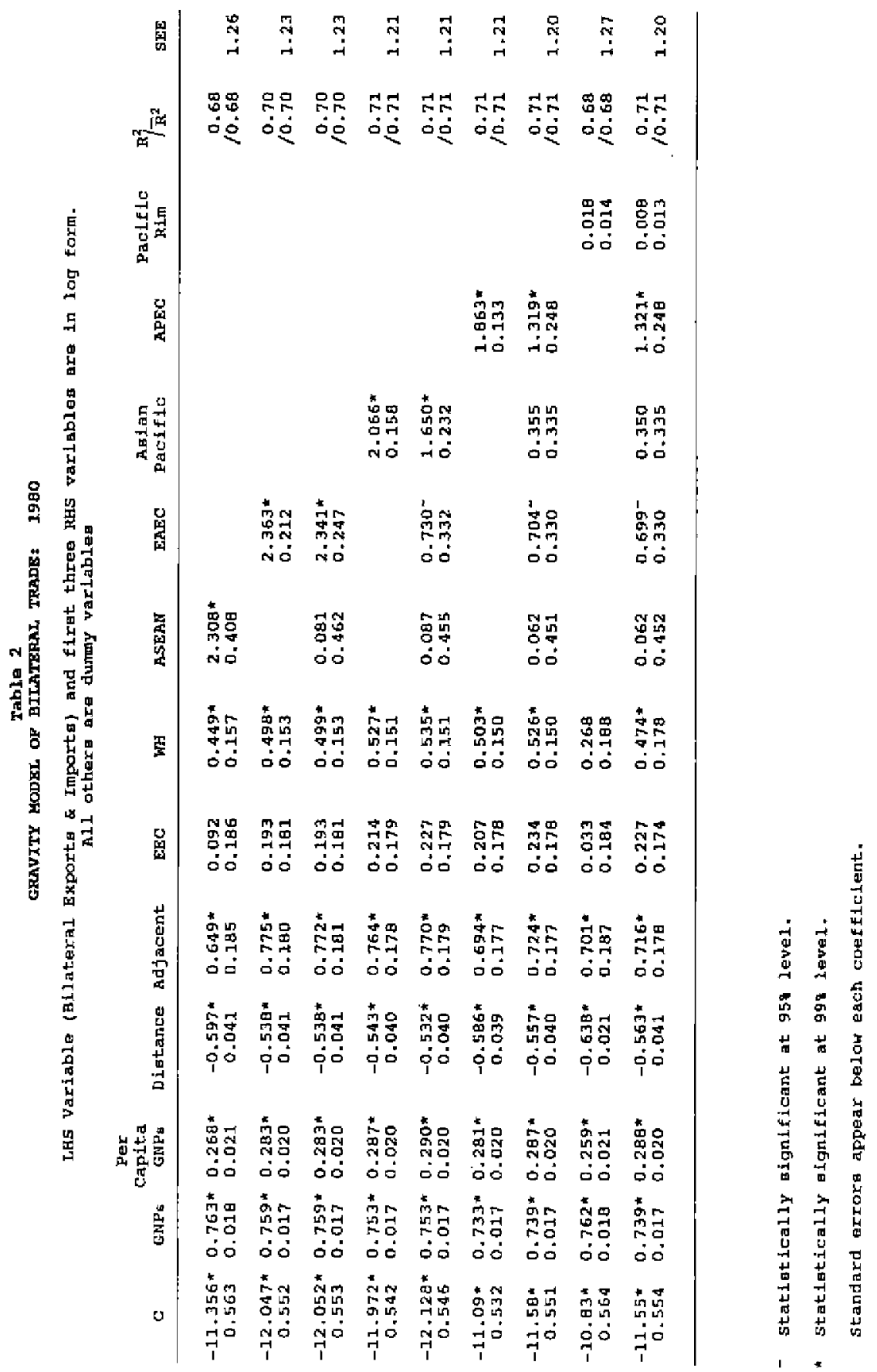




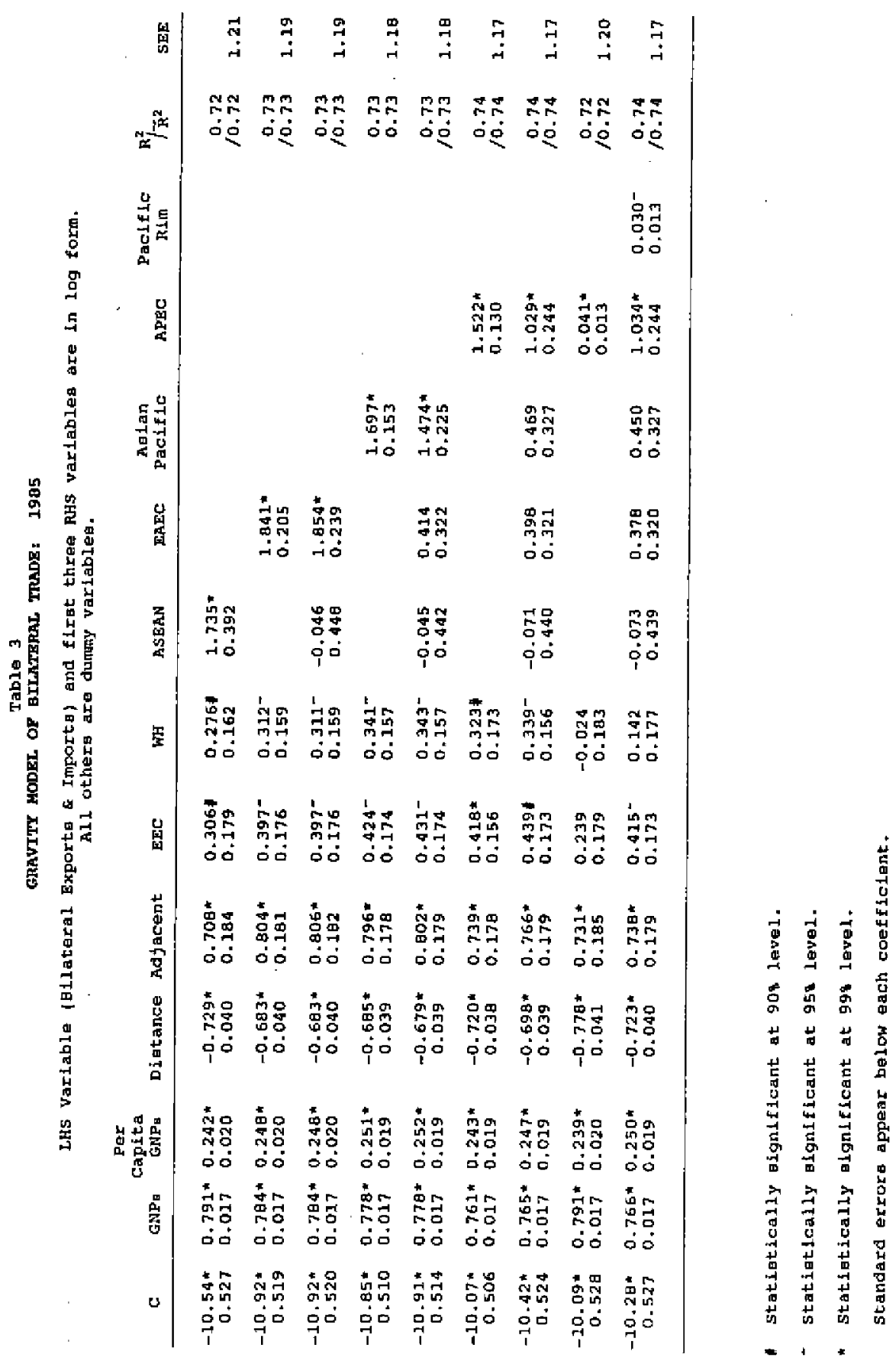




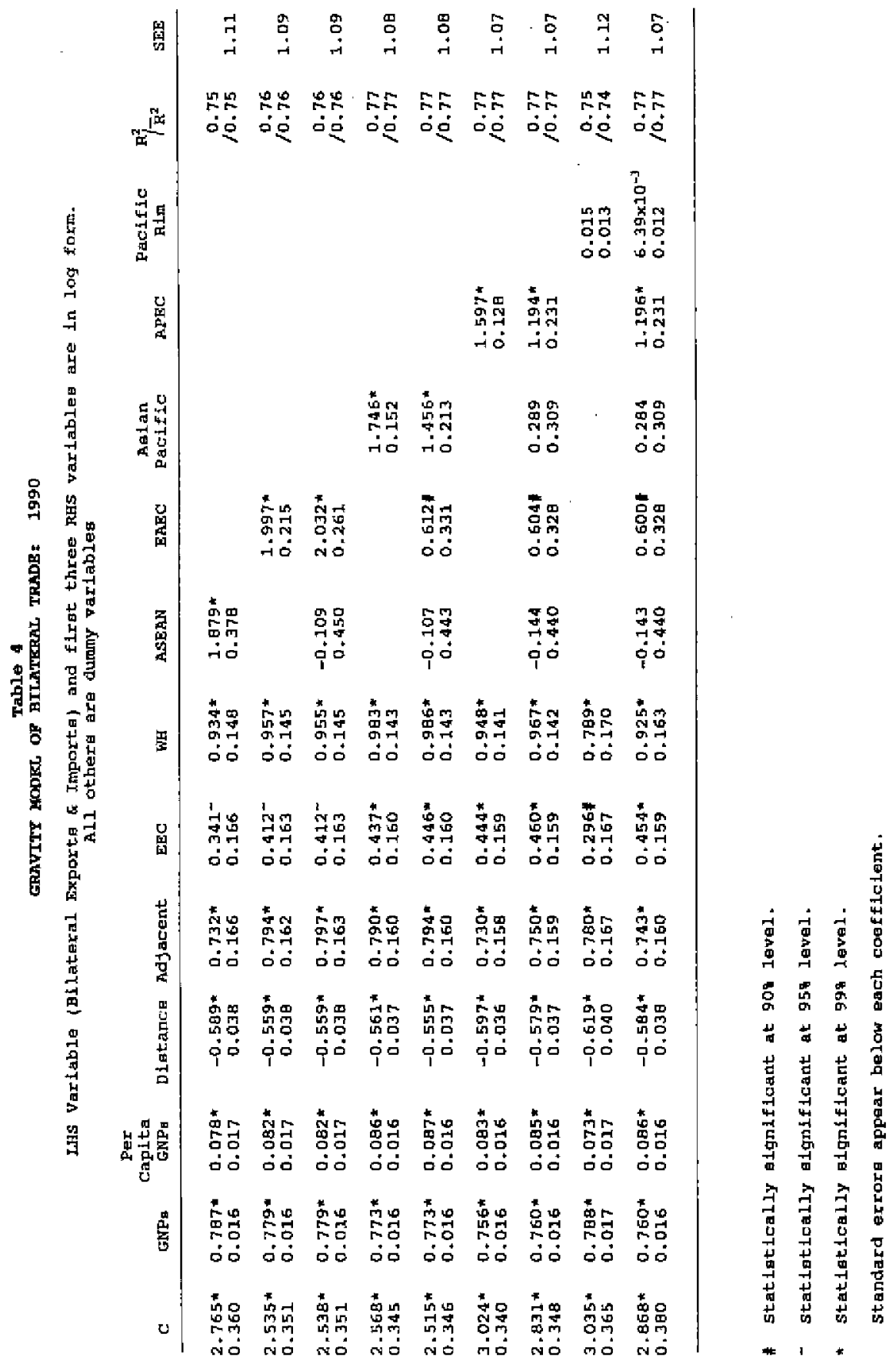


Table 5: Japan's Foreign Direct Investment

Overseas Direct Invegtment by Area and Country

(In millivas of doillers)

\begin{tabular}{|c|c|c|c|c|c|c|c|c|c|}
\hline & \multicolumn{3}{|c|}{ FY 1989} & \multicolumn{3}{|c|}{ FY 1990} & \multicolumn{3}{|c|}{$\begin{array}{c}\text { Cemulntive Tnlal } \\
\text { Fry 1951-1990 }\end{array}$} \\
\hline & Caga & Atnount & 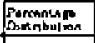 & Case & Almount & $\begin{array}{l}\text { Puranken } \\
\text { Lisinbulion }\end{array}$ & Gane & Allount & 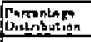 \\
\hline $\begin{array}{l}\text { U. S. A. } \\
\text { Canada } \\
\text { Sublotel (Nordh America) }\end{array}$ & $\begin{array}{r}2,658 \\
180 \\
2,848 \\
\end{array}$ & $\begin{array}{r}32,540 \\
1,362 \\
37,902 \\
\end{array}$ & $\begin{array}{r}4.2 \\
2.0 \\
50.2 \\
\end{array}$ & $\begin{array}{r}2,269 \\
157 \\
2,426 \\
\end{array}$ & $\begin{array}{r}26,128 \\
1,064 \\
27,192 \\
\end{array}$ & $\begin{array}{r}45.9 \\
1.9 \\
47.8 \\
\end{array}$ & $\begin{array}{r}22,944 \\
1,281 \\
24,225 \\
\end{array}$ & $\begin{array}{r}130,529 \\
5,556 \\
116.135 \\
\end{array}$ & $\begin{array}{r}42.0 \\
1.8 \\
40.8 \\
\end{array}$ \\
\hline 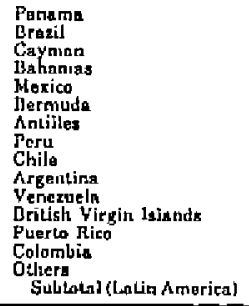 & $\begin{array}{r}263 \\
39 \\
41 \\
14 \\
9 \\
11 \\
8 \\
-10 \\
1 \\
4 \\
4 \\
7 \\
2 \\
17 \\
421\end{array}$ & $\begin{array}{r}2,044 \\
349 \\
1,658 \\
620 \\
30 \\
228 \\
38 \\
-7 \\
47 \\
3 \\
75 \\
118 \\
3 \\
4 \\
19 \\
5,238\end{array}$ & $\begin{array}{l}3.0 \\
0.5 \\
2.5 \\
0.9 \\
0.1 \\
0.5 \\
0.1 \\
0 . \overline{1} \\
0.0 \\
0.1 \\
0.2 \\
0.0 \\
0.1 \\
0.0 \\
7.8\end{array}$ & $\begin{array}{r}206 \\
15 \\
34 \\
4 \\
14 \\
17 \\
7 \\
-5 \\
11 \\
4 \\
9 \\
4 \\
2 \\
3 \\
9 \\
339 \\
\end{array}$ & $\begin{array}{r}1,742 \\
615 \\
588 \\
121 \\
168 \\
360 \\
9 \\
= \\
30 \\
213 \\
77 \\
15 \\
23 \\
59 \\
8 \\
3,028\end{array}$ & $\begin{array}{l}2.4 \\
1.1 \\
1.0 \\
0.2 \\
0.3 \\
0.6 \\
0.0 \\
0 . \\
0.1 \\
0.4 \\
0.1 \\
0.0 \\
0.0 \\
0.1 \\
0.0 \\
0.4\end{array}$ & $\begin{array}{r}3,855 \\
1,461 \\
261 \\
110 \\
274 \\
176 \\
64 \\
96 \\
99 \\
191 \\
113 \\
57 \\
41 \\
65 \\
474 \\
7,197 \\
\end{array}$ & $\begin{array}{r}16,244 \\
6,560 \\
7,732 \\
3,459 \\
1,874 \\
1,578 \\
795 \\
696 \\
311 \\
491 \\
341 \\
305 \\
167 \\
131 \\
259 \\
40,483\end{array}$ & $\begin{array}{l}5.2 \\
2.1 \\
2.4 \\
1.1 \\
0.6 \\
0.5 \\
0.5 \\
0.2 \\
0.1 \\
0.1 \\
0.1 \\
0.1 \\
0.1 \\
0.0 \\
0.1 \\
23.0\end{array}$ \\
\hline 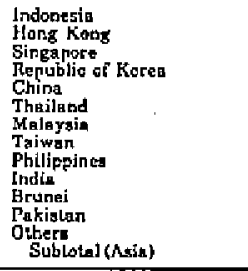 & $\begin{array}{r}140 \\
375 \\
181 \\
81 \\
126 \\
405 \\
159 \\
165 \\
87 \\
9 \\
-5 \\
16 \\
1,707\end{array}$ & $\begin{array}{r}635 \\
1,898 \\
1,902 \\
606 \\
438 \\
1,276 \\
673 \\
494 \\
202 \\
18 \\
0 \\
83 \\
17 \\
8,231\end{array}$ & $\begin{array}{l}0.9 \\
2.8 \\
2.9 \\
0.9 \\
0.6 \\
1.9 \\
1.0 \\
0.7 \\
0.5 \\
0.0 \\
0.0 \\
0.1 \\
0.0 \\
12.2\end{array}$ & $\begin{array}{r}155 \\
244 \\
199 \\
54 \\
165 \\
377 \\
169 \\
102 \\
58 \\
7 \\
\overline{7} \\
26 \\
1,499\end{array}$ & $\begin{array}{r}1,105 \\
1,785 \\
840 \\
284 \\
349 \\
1,154 \\
725 \\
446 \\
258 \\
70 \\
-9 \\
99 \\
7,054 \\
\end{array}$ & $\begin{array}{r}1.9 \\
3.1 \\
1.5 \\
0.5 \\
0.5 \\
2.0 \\
1.3 \\
0.9 \\
0.5 \\
0.1 \\
-\overline{0} \\
0.0 \\
0.1 \\
12,4 \\
\end{array}$ & $\begin{array}{r}1,879 \\
3,743 \\
2,559 \\
1,847 \\
859 \\
2,465 \\
1,509 \\
2,400 \\
850 \\
167 \\
31 \\
58 \\
273 \\
18,634\end{array}$ & $\begin{array}{r}1,540 \\
9,650 \\
4,555 \\
4,139 \\
2,825 \\
4,422 \\
3,201 \\
7,731 \\
1,580 \\
196 \\
109 \\
110 \\
234 \\
47,519\end{array}$ & $\begin{array}{l}3.7 \\
3.2 \\
2.1 \\
1.3 \\
0.9 \\
1.4 \\
1.0 \\
0.9 \\
0.5 \\
0.5 \\
0.0 \\
0.0 \\
0.1 \\
15.9\end{array}$ \\
\hline 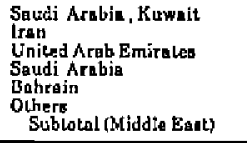 & $\begin{array}{l}- \\
\overline{2} \\
\overline{1} \\
2 \\
5\end{array}$ & $\begin{array}{r}32 \\
1 \\
6 \\
\overline{24} \\
3 \\
60 \\
\end{array}$ & $\begin{array}{l}0.0 \\
0.0 \\
0.0 \\
0.0 \\
0.0 \\
0.1\end{array}$ & $\begin{array}{l}\overline{-} \\
\overline{-} \\
\bar{I}\end{array}$ & $\begin{array}{l}26 \\
- \\
- \\
- \\
-1 \\
2 \pi\end{array}$ & $\begin{array}{c}0.0 \\
- \\
- \\
- \\
\overline{0} .0 \\
0.0\end{array}$ & $\begin{array}{r}4 \\
103 \\
47 \\
101 \\
23 \\
57 \\
340\end{array}$ & $\begin{array}{r}1,441 \\
1,006 \\
442 \\
369 \\
129 \\
45 \\
3,49 !\end{array}$ & $\begin{array}{l}0.5 \\
0.3 \\
0.1 \\
0.1 \\
0.0 \\
0.0 \\
1.1\end{array}$ \\
\hline 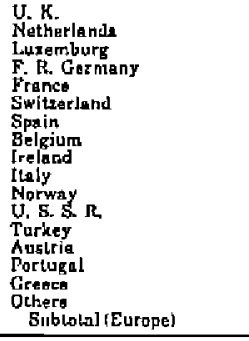 & $\begin{array}{r}285 \\
112 \\
13 \\
119 \\
168 \\
19 \\
58 \\
23 \\
11 \\
47 \\
12 \\
12 \\
4 \\
7 \\
10 \\
15 \\
16 \\
916 \\
\end{array}$ & $\begin{array}{r}5,279 \\
4,547 \\
654 \\
1,083 \\
1,196 \\
397 \\
501 \\
325 \\
139 \\
314 \\
280 \\
19 \\
40 \\
18 \\
74 \\
\overrightarrow{48} \\
14,808 \\
\end{array}$ & $\begin{array}{r}7.3 \\
6.7 \\
1.0 \\
1.6 \\
1.7 \\
0.5 \\
0.7 \\
0.5 \\
0.2 \\
0.5 \\
0.4 \\
0.0 \\
0.1 \\
0.6 \\
0.1 \\
0.1 \\
2.1 \\
1.9\end{array}$ & $\begin{array}{r}270 \\
138 \\
7 \\
134 \\
271 \\
16 \\
43 \\
39 \\
19 \\
32 \\
19 \\
15 \\
6 \\
11 \\
5 \\
5 \\
21 \\
956\end{array}$ & $\begin{array}{r}6,805 \\
2,744 \\
724 \\
1,242 \\
1,257 \\
661 \\
320 \\
367 \\
40 \\
217 \\
138 \\
25 \\
58 \\
38 \\
69 \\
74 \\
71 \\
14,294 \\
\end{array}$ & $\begin{array}{r}12.0 \\
4.8 \\
0.4 \\
2.2 \\
2.2 \\
1.2 \\
0.6 \\
0.0 \\
0.1 \\
0.4 \\
0.2 \\
0.0 \\
0.1 \\
0.1 \\
0.1 \\
0.0 \\
0.1 \\
25.1\end{array}$ & $\begin{array}{r}2,134 \\
780 \\
150 \\
1,1197 \\
3,328 \\
304 \\
320 \\
330 \\
100 \\
397 \\
71 \\
47 \\
14 \\
74 \\
47 \\
18 \\
192 \\
7,425 \\
\end{array}$ & $\begin{array}{r}22,598 \\
12,816 \\
5,607 \\
4,689 \\
4,159 \\
2,495 \\
1,867 \\
1,720 \\
614 \\
900 \\
648 \\
247 \\
224 \\
164 \\
382 \\
201 \\
237 \\
59,265\end{array}$ & $\begin{array}{l}7.3 \\
4.1 \\
1.8 \\
1.5 \\
1.3 \\
0.8 \\
0.6 \\
0.6 \\
0.2 \\
0.3 \\
0.2 \\
0.1 \\
0.1 \\
0.1 \\
0.1 \\
0.0 \\
0.1 \\
19.1\end{array}$ \\
\hline $\begin{array}{l}\text { Liberia } \\
\text { Zaira } \\
\text { Nigeria } \\
\text { Znnubia } \\
\text { O1hora } \\
\text { Stublotal (Nérica) }\end{array}$ & $\begin{array}{c}72 \\
-1 \\
\overline{15} \\
88\end{array}$ & $\begin{array}{r}647 \\
\frac{1}{27} \\
671 \\
\end{array}$ & $\begin{array}{l}1.0 \\
\overline{0} \\
\overline{0} \\
0 . \overline{0} \\
1,0\end{array}$ & $\begin{array}{c}50 \\
-2 \\
\frac{1}{18} \\
70\end{array}$ & $\begin{array}{r}501 \\
-1 \\
\overline{19} \\
551\end{array}$ & $\begin{array}{l}0.9 \\
\overline{0} \\
\overline{0} \\
0 . \overline{1} \\
1.0\end{array}$ & $\begin{array}{r}930 \\
50 \\
93 \\
17 \\
562 \\
1,454 \\
\end{array}$ & $\begin{array}{r}4,552 \\
282 \\
159 \\
142 \\
4: 2 \\
5,826 \\
\end{array}$ & $\begin{array}{l}1.6 \\
0.1 \\
0.1 \\
0.0 \\
0.1 \\
1.9\end{array}$ \\
\hline 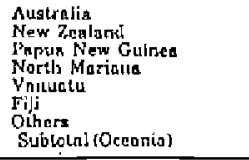 & $\begin{array}{r}448 \\
47 \\
6 \\
62 \\
8 \\
32 \\
33 \\
604\end{array}$ & $\begin{array}{r}4,256 \\
101 \\
10 \\
124 \\
40 \\
19 \\
86 \\
4,618\end{array}$ & $\begin{array}{l}6.3 \\
0.2 \\
0.0 \\
0.2 \\
0.1 \\
0.0 \\
0.1 \\
6.8\end{array}$ & $\begin{array}{r}407 \\
46 \\
4 \\
48 \\
3 \\
26 \\
38 \\
572\end{array}$ & $\begin{array}{r}3,569 \\
291 \\
9 \\
1.74 \\
4 \\
47 \\
72 \\
4,160\end{array}$ & $\begin{array}{l}6.4 \\
0.4 \\
0.0 \\
0.2 \\
0.0 \\
0.1 \\
0.7 \\
7.3\end{array}$ & $\begin{array}{r}2,760 \\
471 \\
213 \\
328 \\
67 \\
97 \\
128 \\
0,957\end{array}$ & $\begin{array}{r}16.060 \\
926 \\
22 \pi \\
456 \\
108 \\
108 \\
212 \\
18.098\end{array}$ & $\begin{array}{l}5.2 \\
0.3 \\
0.1 \\
0.1 \\
0.0 \\
0.0 \\
0.1 \\
5.8\end{array}$ \\
\hline Total & 0,589 & 67,510 & 100,0 & $5,6 G\rfloor$ & 50,911 & $\mathbf{1 0 0 . 0}$ & 53,2, & 310,408 & 200.0 \\
\hline
\end{tabular}

Source: Financial Statistics of Tapan, 1991, Ministry of Finance, p. 95. 


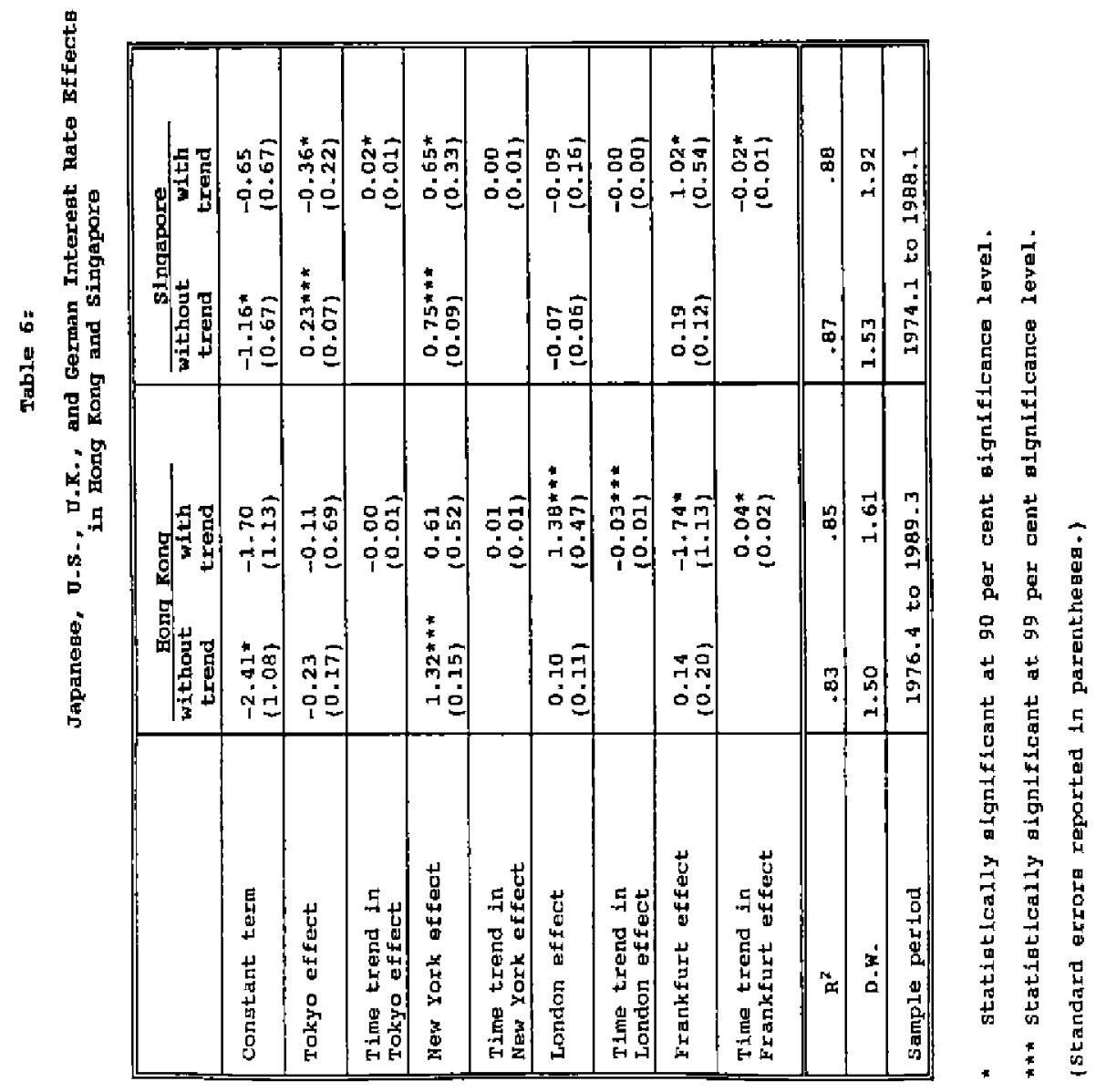


Table 7:

Japanese and 0.3 . Intereat Rate Effecte in Flve Paciflc Countrieg

Regresglong of local interegt rate agalngt:

1) Japanege and U.S. Interegt rate日

2) Japaneae and U.S. Interest rates adjusted for expectations

of exchange rate changeg as reflected in Currency Forecagterg' Digegt

3) Japaneas and U.S. Interest rates adjustec for forward diacount

\begin{tabular}{|c|c|c|c|c|c|}
\hline & $\begin{array}{c}\text { Congtant } \\
\text { term }\end{array}$ & $\begin{array}{r}\text { Tokyo } \\
\text { effect }\end{array}$ & $\begin{array}{c}\text { New York } \\
\text { effect }\end{array}$ & $R^{2}$ & D.พ. \\
\hline $\begin{array}{l}\text { sing- } \\
\text { apore I) }\end{array}$ & $\begin{array}{l}-2.29 * * \star \\
(0.84)\end{array}$ & $\begin{array}{l}0.82 * \pi * \\
(0.07)\end{array}$ & $\begin{array}{l}0.43 * \pi * \\
(0.09)\end{array}$ & .85 & 0.53 \\
\hline 2) & $\begin{array}{l}3.30 * \pi \star \\
(0.39)\end{array}$ & $\begin{array}{l}-0.01 \\
(0.03) \\
\end{array}$ & $\begin{array}{l}0.27 * \pi \star \\
(0.05)\end{array}$ & .71 & 0.43 \\
\hline 3) & $\begin{array}{l}I .47 \div * \star \\
(0.45) \\
\end{array}$ & $\begin{array}{l}0.29 \pm= \pm \\
(0.05) \\
\end{array}$ & $\begin{array}{l}0.41 \pm=* \\
(0.06)\end{array}$ & .72 & 1.41 \\
\hline $\begin{array}{l}\text { Augtra- } \\
\text { lia 1) }\end{array}$ & $\begin{array}{l}-6.66 \pm t \\
(2.32) \\
\end{array}$ & $\begin{array}{l}0.74 * * n \\
(0.18)\end{array}$ & $\begin{array}{l}2+11 * * \cdots \\
(0.26)\end{array}$ & .73 & 0.19 \\
\hline 2) & $\begin{array}{l}13.90 * * * \\
(1.40)\end{array}$ & $\begin{array}{r}0.10 * \\
(0.06)\end{array}$ & $\begin{array}{l}-0.07 \\
(0.12) \\
\end{array}$ & .03 & 0.20 \\
\hline 3) & $\begin{array}{l}3.83 \pi k \star \\
(1.13)\end{array}$ & $\begin{array}{c}0.07 \\
(0.21) \\
\end{array}$ & $\begin{array}{l}0.67 * \pi * \\
(0.20)\end{array}$ & .76 & 1.36 \\
\hline $\begin{array}{r}\text { Talwan } \\
1\end{array}$ & $\begin{array}{l}-4.93 \\
(4.04)\end{array}$ & $\begin{array}{l}1.91 \text { * * } \\
(0.32)\end{array}$ & $\begin{array}{l}0.32 \\
(0.45) \\
\end{array}$ & .53 & 1.17 \\
\hline 2) & $\begin{array}{r}7.14 \\
(0.67) \\
\end{array}$ & $\begin{array}{c}0.07 \\
(0.08) \\
\end{array}$ & $\begin{array}{c}0.10 \\
(0.12) \\
\end{array}$ & .05 & 0.82 \\
\hline $\begin{array}{r}\text { Rorea } \\
11 \\
\end{array}$ & $\begin{array}{r}-4.08 * \\
(2.33) \\
\end{array}$ & $\begin{array}{l}1.29= \pm= \\
(0.19)\end{array}$ & $\begin{array}{l}1.16 * * * \\
(0.26)\end{array}$ & .69 & 0.78 \\
\hline 2) & $\begin{array}{l}11.65 \pi * * \\
(0.32)\end{array}$ & $\begin{array}{c}0.04 \\
(0.04)\end{array}$ & $\begin{array}{l}0.27 \text { ** } \\
(0.07)\end{array}$ & .55 & $1.2 \mathrm{\theta}$ \\
\hline $\begin{array}{l}\text { Hong } \\
\text { Kong 1) }\end{array}$ & $\begin{array}{l}-6.40= \pm \\
(1.51)\end{array}$ & $\begin{array}{r}0.25 * \\
0.15\rangle\end{array}$ & $\begin{array}{l}1.66 * * * \\
(0.17)\end{array}$ & .79 & 0.59 \\
\hline
\end{tabular}

* Statiotically different from zero at 90 aignificance level.

*** Btatlotlcally alfferent from zero at. 99 glgniflcance level.

(Standard errorg are reported in parenthegeg.) 


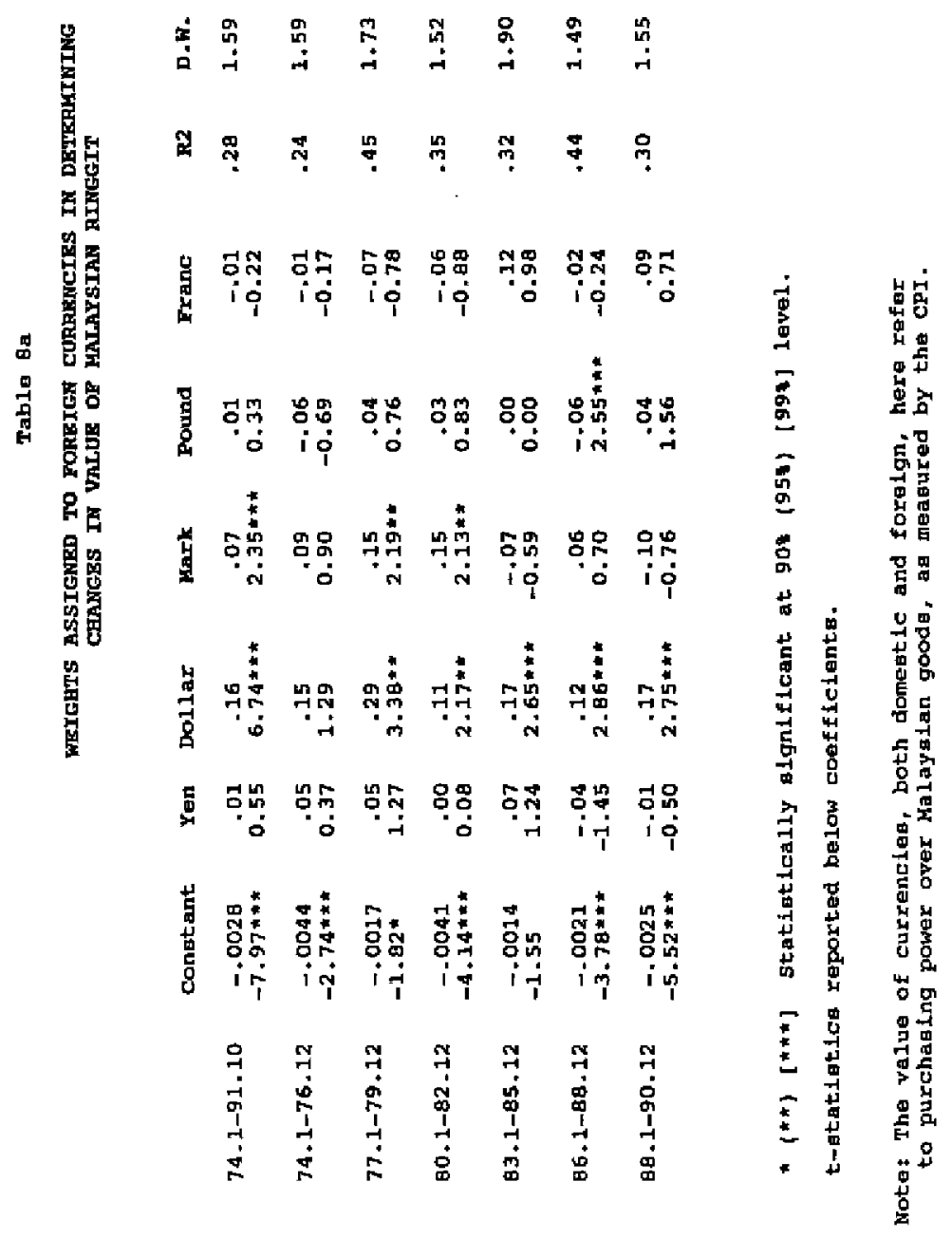




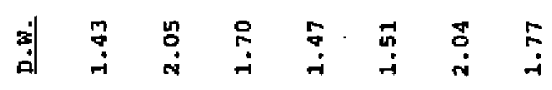

ข

总

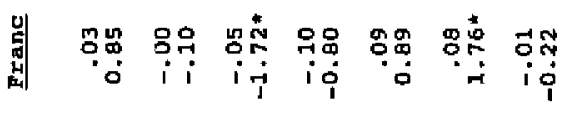

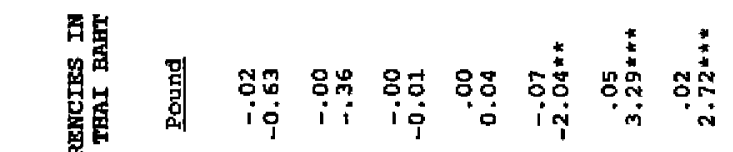

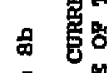

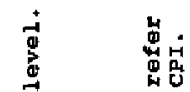

密

吕

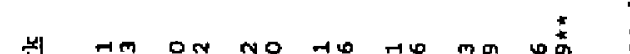

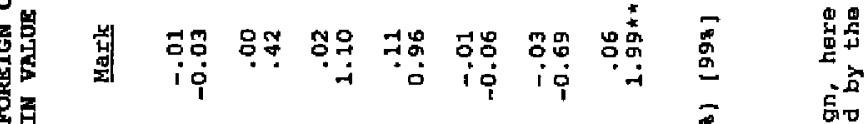

* * * * * * * *

矛 品

案

量

可

菊 落

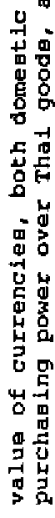

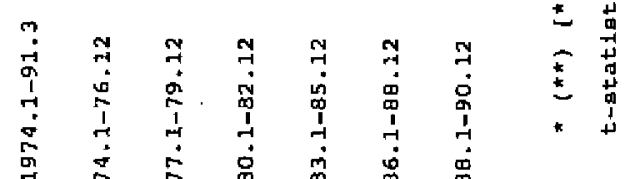

䁬

$\stackrel{\text { गे }}{\stackrel{0}{2}}$ 


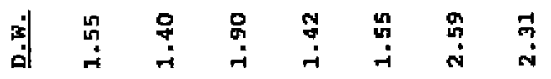

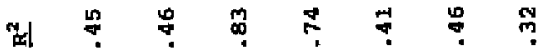

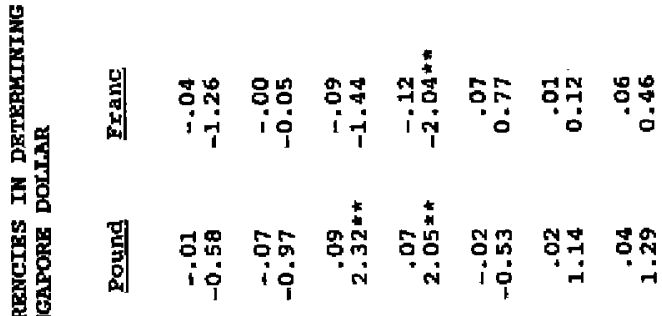

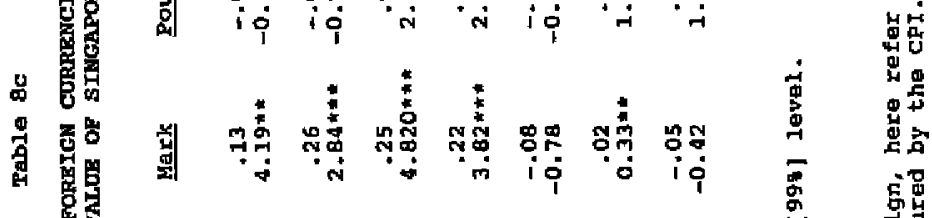

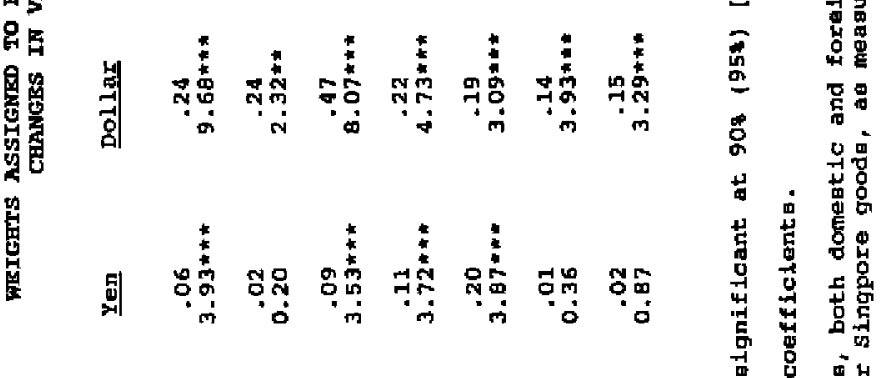

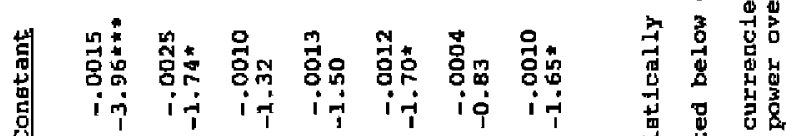

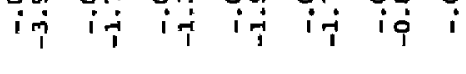

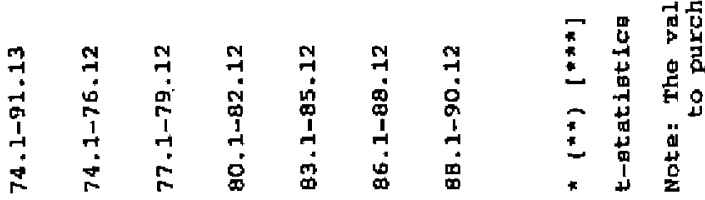


Table 9

Share of the Yen in Debt-Denomination and Official Reperve Holdinge

In per cent

\begin{tabular}{|c|c|c|c|c|c|c|c|c|}
\hline & \multicolumn{6}{|c|}{$\begin{array}{c}\text { Yen ghare in external debt } \\
\text { of five countries }\end{array}$} & \multicolumn{2}{|c|}{$\begin{array}{l}\text { Yen ahare in } \\
\text { official } \\
\text { haldinge }\end{array}$} \\
\hline & $\begin{array}{l}\text { Indo- } \\
\text { negla }\end{array}$ & Raréa & $\begin{array}{l}\text { Mal- } \\
\text { aysia }\end{array}$ & Phil. & $\begin{array}{l}\text { Thai- } \\
\text { land }\end{array}$ & $\begin{array}{l}\text { Total } \\
\text { of } 5\end{array}$ & A自淐 & World \\
\hline 1980 & 20.0 & 16.6 & 19.0 & 22.0 & 25.5 & 19.5 & 13.9 & 4.4 \\
\hline 1901 & 19.3 & 14.1 & 16.9 & 20.6 & 23.2 & 17.8 & 15.5 & 4.2 \\
\hline 1982 & 21.0 & 12.3 & 13.3 & 19.2 & 24.0 & 17.2 & 17.6 & 4.7 \\
\hline 1983 & 23.3 & 12.5 & 14.2 & 20.0 & 27.3 & 18.5 & 15.5 & 5. \\
\hline 1984 & 25.0 & 12.0 & 21.2 & 20.0 & 29.2 & 20.3 & 16.3 & 5.8 \\
\hline 1955 & 31.7 & 16.7 & 26.4 & 24.9 & 36.1 & 25.8 & 26.9 & B.o \\
\hline 1906 & 33.9 & 22.0 & 30.4 & 25.5 & 39.9 & 29.3 & 22.9 & 7.9 \\
\hline 1987 & 39.4 & 27.2 & 35.7 & 35.2 & 43.1 & 36.0 & 30.0 & 7.5 \\
\hline 1988 & 39.3 & 29.5 & 37.1 & 40.5 & 43.5 & 37.9 & 26.7 & 7.7 \\
\hline 1989 & 35.2 & 26.6 & 36.6 & 32.6 & 40.9 & 35.7 & 17.5 & 7.9 \\
\hline 1990 & & & & & & & 17.1 & 9.1 \\
\hline
\end{tabular}

-Selected Agian countrlea (not 1ncluding Japan).

Source, Tavlas and Ozekl (1992, p.39). 
Table 10

Shace of the Yen in Dencmination of Porelgn Trade

In per cent

\begin{tabular}{|c|c|c|c|c|}
\hline & Denominetion & of exportg & Denomination & of 1mporta \\
\hline & Southeagt Agla & All reglons & Southeagt $\mathrm{n}=1 \mathrm{a}$ & Al.1 reglons \\
\hline 1983 & 48.0 & 40.4 & 2.0 & 3.0 \\
\hline 1986 & 37.5 & 35.5 & 9.2 & 9.7 \\
\hline 1987 & 35.3 & 34.7 & 13.9 & 11.6 \\
\hline 1988 & 41.2 & 34.3 & 17.5 & 13.3 \\
\hline 1989 & 43.5 & 34.7 & 19.5 & $14-1$ \\
\hline 1990 & $4 \mathrm{~B} .9$ & 37.5 & 19.4 & 14.4 \\
\hline
\end{tabular}

Source; Japanege Minietry of Flnance, Annual Report, as reported In Tavias and ozeki (1992, p.33). 